\title{
River Basins of Imo State for Sustainable Water Resources Management
} BC Okoro ${ }^{1 *}$, RA Uzoukwu² and NM Chimezie ${ }^{2}$

${ }^{1}$ Department of Civil Engineering, Federal University of Technology, Owerri, Imo State, Nigeria

${ }^{2}$ Department of Civil Engineering Technology, Federal Polytechnic Nekede, Owerri, Imo State, Nigeria

\begin{abstract}
The river basins of Imo state, Nigeria are presented as a natural vital resource for sustainable water resources management in the area. The study identified most of all the known rivers in Imo State and provided information like relief, topography and other geographical features of the major rivers which are crucial to aid water management for a sustainable water infrastructure in the communities of the watershed. The rivers and lakes are classified into five watersheds (river basins) such as Okigwe watershed, Mbaise / Mbano watershed, Orlu watershed, Oguta watershed and finally, Owerri watershed. The knowledge of the river basins in Imo State will help analyze the problems involved in water resources allocation and to provide guidance for the planning and management of water resources in the state for sustainable development.
\end{abstract}

Keywords: Rivers; Basins/Watersheds; Water allocation; Sustainability

\section{Introduction}

An understanding of the hydrology of a region or state is paramount in the development of such region (state). Imo state, Nigeria is highly drained by rivers and lakes. If properly harnessed, the water resources of the state, it will enhance her socio-economic development. The development will not be feasible without an in-depth knowledge of the location, direction and other properties of flow of rivers through an articulated inventory. Hydrology is an earth science which deals with the occurrence, properties, circulation and distribution of water upon, over and beneath the earth surface [1-3]. Wisler and Brater [4] observed that hydrology is a science that deals with the depletion and replenishment of water resources of the land area of the earth. The knowledge of hydrology is one of the key ingredients in decision-making processes where water is involved [5]. Topics requiring expertise in river basins are far-ranging and they include water supply development and management; treated wastewater disposal; floodplain management; wetland protection; preservation, protection and restoration of natural systems; water resources management; habitat protection; solid waste landfill design, and groundwater protection and development $[5,6]$.

According to [7], the availability of water from various sources is estimated by a good knowledge of hydrology of the places. In river basin development, it is necessary to compute accurate estimate of rainfall excess for a given storm in order to forecast floods from total yield of the basin. Knowledge of the accurate estimates is vital to the formulation of various projects within a river basin. Thus, for the design and operation of engineering projects in an area, it is the duty of all those concerned with water resources development to ensure a study of the area's river basins in-depth. Reddy [8] suggested that river basin development and control of water resources has an important influence on agriculture, forestry, geography, watershed management, political science, economics and sociology. Proper use of a river basin has practical applications in structural design, water supply, waste water disposal and treatment, irrigation, drainage, hydropower, flood control, navigation, erosion and sedimentation control, salinity control, pollution abatement, recreational use of water, fish and wild life preservation, insect control and coastal works. Therefore, proper knowledge of the rivers, lakes and creeks in Imo state, Nigeria will assist in providing answers to the following questions as it provides the foundation and requirements for a sustainable water infrastructure in the cities, communities and local government areas of the state.

- What maximum flows, after different years, are expected at a spillway, or a highway culvert in a city drainage system?
- What minimum reservoir capacity will be sufficient to assure adequate water for irrigation or municipal water supply, during droughts?

- How much quantity of water will become available at a reservoir site, and when will it become available? In other words, what will be the available possible supplies at the reservoir site?

- What effects will be there on the river water levels after the construction of proposed reservoir, levees, or other controlling structures?

Communities face a lot of challenges with respect to meeting their water needs. These challenges include increased water scarcity and/ or flooding associated with climate variability, economic uncertainty, aging and degrading infrastructures, pollution and impaired water resources and a broad range of stakeholders with poor understanding of water issues. This study will help to overcome these challenges and will help to organize and operate key sustainability principles and practices.

\section{The river basin}

Lakes, wetlands, rivers and aquifers are the world's useable renewable freshwater resources. A river or lake basin is the area bounded by the watersheds of a system of streams and rivers that flow towards the same outlet. In the case of rivers this is generally the sea, but may be an inland water body, such as a lake or swamp. A groundwater basin or aquifer is a discrete body of underground water [9]. Other names for river basin are watershed or catchment. The basin has been recognized as a practical hydrological unit for water resources management.

Global Water Partnership and International Network of Basin Organizations [9] stressed that water management has always been a major problem in many regions because of the natural variability and uncertainty in weather patterns. With climate change this problem is

${ }^{*}$ Corresponding author: B. C. Okoro, Department of Civil Engineering, Federal University of Technology, Owerri, Imo State, Nigeria, Tel:234-083-508-6235; Email: bc1okoro@yahoo.com

Received December 03, 2013; Accepted January 07, 2014; Published January 13, 2014

Citation: Okoro BC, Uzoukwu RA, Chimezie NM (2014) River Basins of Imo State for Sustainable Water Resources Management. J Civil Environ Eng 4: 134 doi:10.4172/2165-784X.1000134

Copyright: $(2014$ Okoro BC, et al. This is an open-access article distributed under the terms of the Creative Commons Attribution License, which permits unrestricted use, distribution, and reproduction in any medium, provided the original author and source are credited. 
likely to get worse. In some basins, changes in climate will mean less rainfall and lower rivers flows, while in other basins; climate change will mean more floods. These changes will be exacerbated because of other variations such as population and economic growth, urbanization and rising demands for food, which increase the demand for water, and degrade water sources and aquifers in basins where water is already scarce.

The basin manager now faces huge pressures, risks and conflicts in balancing economic development with maintaining healthy water resources. The challenge for governments and basin managers is to balance development with sustainability whereby finding smarter ways to develop and manage water resources and finding responses appropriate to the circumstances in each particular basin. The interconnected nature of water management within a basin directly impacts communities, administrative regions and political territories (provinces, nations). Basin managers must find ways to address these water-related challenges in order to avert problems, such as social unrest, conflict between states, slowing of economic development and degradation of vital resources [9].

\section{The Study Area}

Imo State is one of the 36 states of Nigeria and one of the five states that make up the South East Geo-political zone in the south eastern part of Nigeria. Owerri is the capital and the largest city in Imo State. Imo state lies within latitudes $4^{\circ} 45^{\prime} \mathrm{N}$ and $7^{\circ} 15^{\prime} \mathrm{N}$ and longitudes $6^{\circ} 50^{\prime}$ $\mathrm{E}$ and $7^{\circ} 25^{\prime} \mathrm{E}$. It occupies the area between the lower part of River Niger and the upper and middle of Imo River from which it derives its name (Figure 1). It is bounded on the east by Abia State, on the west by the River Niger and Delta state and on the north by Anambra state. Rivers state lies on the south of Imo state. Besides Owerri, Imo state is made up of twenty-seven Local Government Areas (Figure 2). The major towns in the State are Isu, Okigwe, Oguta, Orlu, Mbaise, Mbano, Mbieri, Orodo and Orsu. Imo State occupies an area of about 5,100 km². It has an estimated population of 4.8 million and the population density varies from 230-1,400 people per square kilometer [10]. Imo state is a predominantly Igbo speaking state, with Igbo people constituting a majority of $98 \%$.

The topography, relief and morphology of the drainage area of
Imo State show that strong relief occurred in limited areas. The state lies on the Benin formation of coastal plain sands which is made up of deep, porous, infertile and highly leached soil. The north zone of the state is predominantly occupied by the plateau and escarpment of highlands with relatively steep slopes. The northern zone is also known as the Okigwe Zone of the state and it contains impermeable layers of clay near the surface. The soil in other areas of the state consists of laterite material, under a superficial layer of fine grained sand. There is homogeneity of the rock structures. The vast low-lying areas are underlain by the coastal plain sands within the Niger Delta region of Nigeria.

The climate of Imo state has been known to be humid. Temperatures are similar all over the state. The mean annual temperature is $20^{\circ} \mathrm{C}$. It has an average relative humidity of 75 percent during the rainy season. Imo state is characterized by an equatorial climate with a mean annual rainfall of between $1800 \mathrm{~mm}$ and $2500 \mathrm{~mm}$ [11]. The abundant rainfall feeds the large and extensive hydrologic system. Mean annual rainfall (MAR) is highest in the south as a result of the humid air current coming off from the ocean. This thereby releases moisture as it moves across the landmass of the state and its environs. The mean annual rainfall declines from $2500 \mathrm{~mm}$ in the south to less than $2000 \mathrm{~mm}$ in the north of the state. Rainfall undoubtedly is the most important climate variable that has a far reaching influence in stream flow behavior. The amount of stream flow is determined by the effective rainfall, porosity and near surface permeability. Most river valleys are fed by available runoff. There is high dependence on land and agriculture. The people are predominantly farmers and fishermen. Their activities influence the hydrologic regime of the basins in which it belongs.

\section{Major rivers/Lake in Imo state}

Chimezie [12] observed that Imo state belongs to the larger Niger Delta Basin of Nigeria and specifically is of the Imo River Basin which drains by a number of rivers, streams, lakes and creeks into the Imo River (Figure 3). It is highly drained by surface rivers in the north and a few in the south. The river system that follow the outcrop of large impermeable shale bodies are characterized by fluctuating flow rate due to low infiltration and again the stream level is determined by the seasonal rainfall. Chimezie [12] further observed that the major sandstone formations in the Imo state

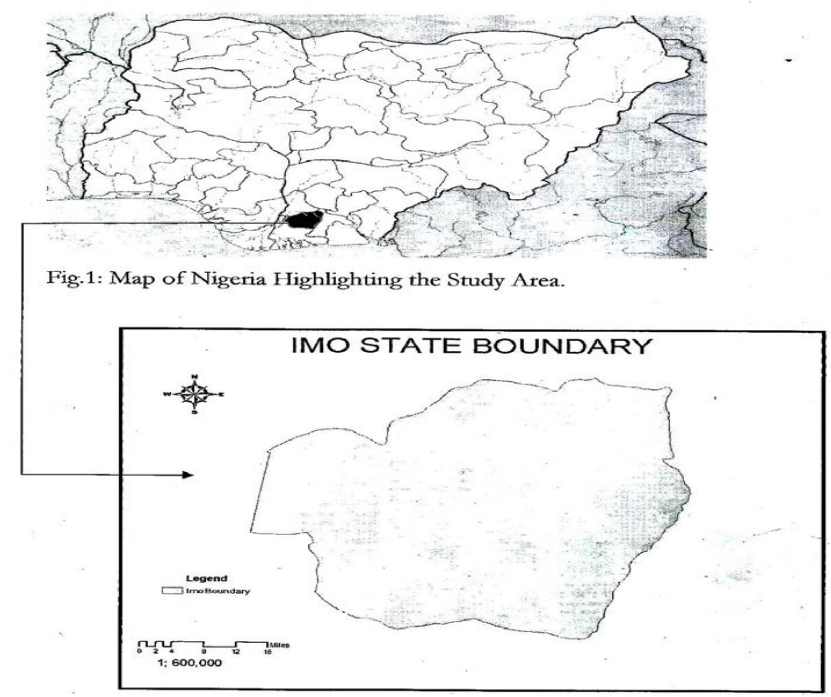

Figure 1: Map of Nigeria Highlighting the Study Area and Map of Imo State, Nigeria showing the study area. 


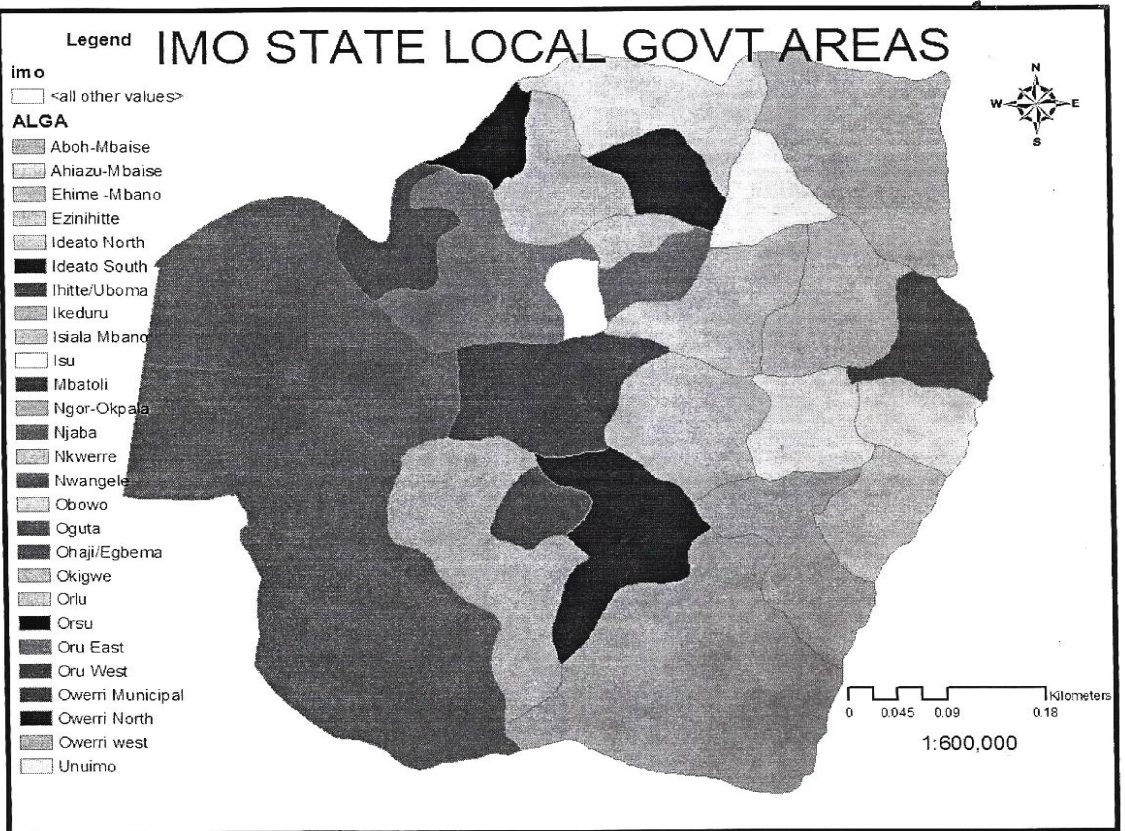

Figure 2: Map of Imo state showing Local Government Area Boundaries.

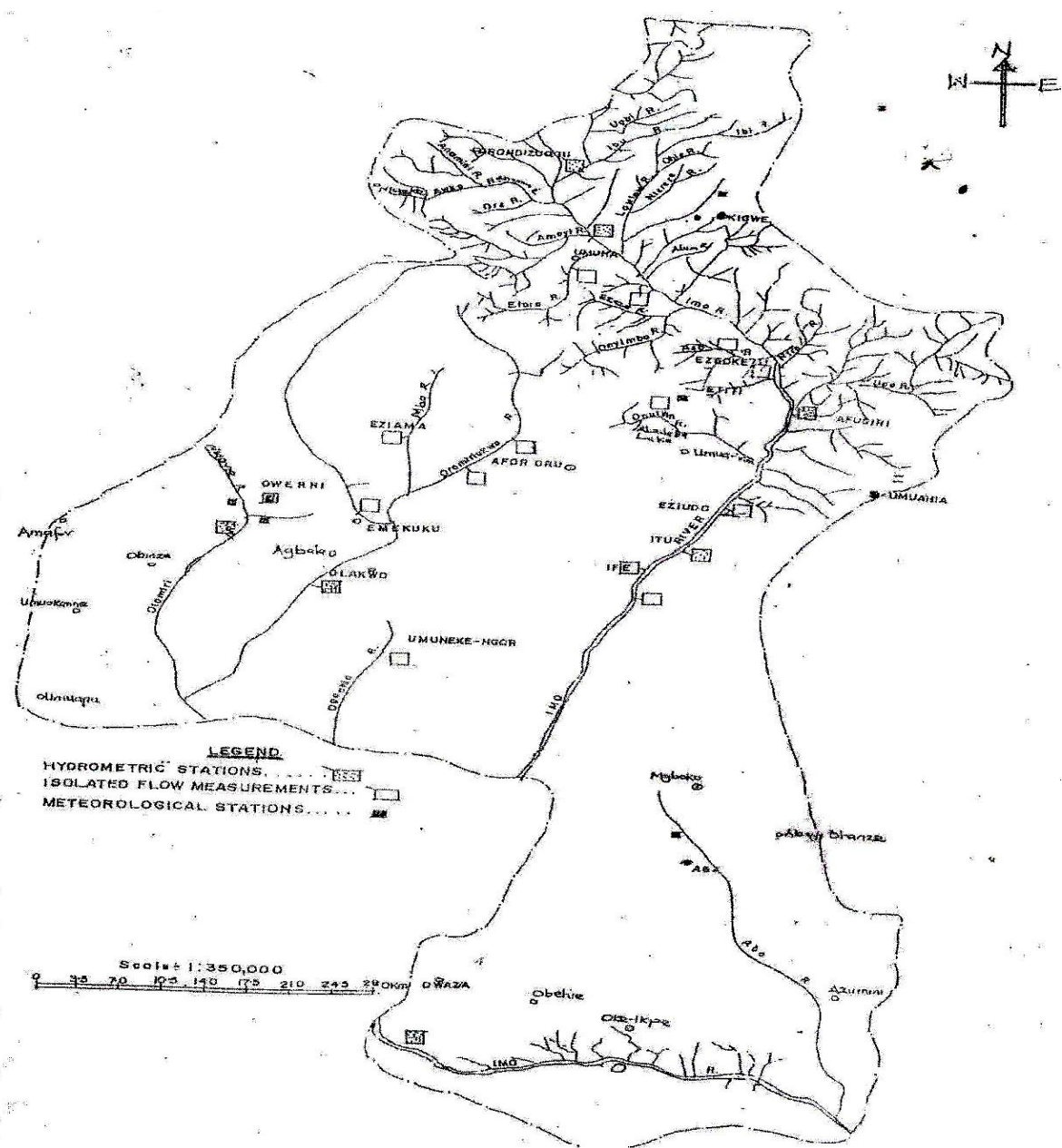

Figure 3: Imo River Basin showing rivers in Imo state \{Source: Atlas of Imo State (1984), Ministry of Lands, Survey and Urban Planning, Owerri, Imo State\}. 
have high porosity and moderately high permeability, and a large percentage of the seasonal precipitation stored as ground water and released to surface drainage system in accordance with the natural equilibrium of the hydrologic system. The aim of this study is to identify and document the rivers, streams, lakes, creeks, and river basins that drain Imo state, and outline their water resources potentials for the state.

Imo River is the major river in Imo state with a large number of tributaries. Imo River being the most prominent, traverses from north to south of the state with a length of about $225 \mathrm{~km}$. In its upper reach, it receives tributaries. It has its source in the Ideato North Area of Imo State near Osina. Its middle reaches flow north to south for some $80 \mathrm{~km}$ in the flat valley through the coastal plain lowland without receiving any significant tributaries. The Imo River drained not only Imo State but also Abia and Akwa Ibom States and empties into the Atlantic Ocean. It is joined by Aba River flowing from the North and then enters Akwa Ibom State enroute to the Ocean. The major tributary of Imo River is the Otamiri River.

The Otamiri River is one of the main rivers in Imo State. The river has its source at Egbu from where it runs south past Owerri city and through Nekede, Ihiagwa, Eziobodo, Olokwu, Umuisi, Mgbirichi and Umuagwo to Ozuzu in Etche, Rivers State, from where it flows to the Atlantic Ocean. The Otamiri River has a length of about 105km [13]. The length of Otamiri River from its source to its confluence at Emeabiam with the Uramiriukwa River is $30 \mathrm{~km}$. The Otamiri watershed covers about $10,000 \mathrm{~km}^{2}$ with annual rainfall between 2250 and $2500 \mathrm{~mm}$. The watershed is mostly covered by depleted rain forest vegetation, with mean temperature of $27^{\circ} \mathrm{C}$ throughout the year [14]. The Otamiri River is joined by the Nworie River at Nekede in Owerri. Waste management in Owerri generally is inefficient and contributes to pollution of the Nworie River. Most of the wastes, from Owerri municipality are dumped at the Avu landfill in Owerri West on the Port Harcourt highway, which creates a high concentration of phosphate and nitrate that infiltrate into the Otamiri River south of Owerri. Otamiri River flows through an alternating sequence of sands, sandstones and clayshales [15]. Random sand samples from the banks of Otamiri River between Chokocho and Umuanyaga, Etche Local Government Area and Rivers state showed that $86 \%$ of the sand particles are within the ideal range for glass making.

Nworie River is a tributary of the Otamiri River. Nworie River is about $9.2 \mathrm{~km}$ in length. The Nworie River is subject to intensive human and industrial activities and is used as a source of drinking water by the poor, when the public water system fails. The Nworie River is polluted by organic wastes, but in 2008 was reported above acceptable levels of chemical pollution [16].

Oguta Lake is one of the natural water resources of non-marine habitat located in a low-lying (elevation $<50 \mathrm{~m}$ ) platform. The lake precisely lies between latitudes $5^{\circ} 41^{\prime} \mathrm{N}$ and $5^{\circ} 44^{\prime} \mathrm{N}$ and longitudes $6^{\circ} 45^{\prime}$ $\mathrm{E}$ and $6^{\circ} 50^{\prime} \mathrm{E}$ in the equatorial rainforest belt of Nigeria. Oguta Lake is a very small lake compared to man-made and natural lakes in Nigeria like Lake Chad, Kainji and Tiga Lakes. It is also the largest freshwater system in southeastern Nigeria. Oguta Lake is of great importance to both the Imo state government of Nigeria as a focal point for sporting, research and tourism development, and to the local population, it is their main source of domestic water supply. The Lake is also used for recreation, fishing, transportation and sand mining activities. The Oguta Lake lies within the Benin Formation. The Benin Formation consists of continental sands with traces of clay/shale and some isolated units of gravel, conglomerate and sandstones [17]. Ogidi and Nwadiaro [18] studied the surface geology of Oguta Lake area using road cuts and low hills and observed that it consists of ferruginized sands which are occasionally massively bedded and pebbly.

Four rivers (Njaba, Awbana, Utu and Orashi) are tributaries to Oguta Lake [19]. The Njaba and Awbana discharge into the lake all the year round while Utu Stream flows in during the rainy season. The Orashi River flows past the lake in its southwestern portion. The total annual inflow from the rivers and stream is about $25,801.60 \mathrm{~m}^{3}[20]$. The annual return and overland flow into the lake is estimated to be about $69,000 \mathrm{~m}^{3}$ and $138,000 \mathrm{~m}^{3}$, respectively while the annual recharge of the lake from precipitation is about $693,000 \mathrm{~m}^{3}$. The annual groundwater inflow into the lake is estimated at about $2,750,400 \mathrm{~m}^{3}$. The total annual water inflow greatly outweighs the total annual outflow [20]. The Oguta Lake is adequately recharged all the year round. The rivers and lakes of Imo state, Nigeria is shown in (Table 1 and Figure 3).

\begin{tabular}{|c|c|c|c|c|c|}
\hline S. No. & Names & Origin/ Location & Destination & Status & River Basin / Water Shed \\
\hline 1 & Ibi river & Okigwe & Law Law River & Tributary & Okigwe water shed / River Basin \\
\hline 2 & Ibu River & Nneafor & Imo River & " & " \\
\hline 3 & Efuru River & Okigwe & Imo River & $"$ & $"$ \\
\hline 4 & Ikwo River & Okigwe & Imo River & $"$ & $"$ \\
\hline 5 & Abuba River & Okigwe & Imo River & $"$ & $"$ \\
\hline 6 & lyba River & Okigwe & Imo River & $"$ & $"$ \\
\hline 7 & Idiu River & Okigwe & Imo River & $"$ & $"$ \\
\hline 8 & Ibu River & Okigwe & & $"$ & $"$ \\
\hline 9 & Nterere River & Okigwe & Imo River & $"$ & $"$ \\
\hline 10 & Ife River & Okigwe & Imo River & $"$ & $"$ \\
\hline 11 & Izeh River & Okigwe & Imo River & $"$ & $"$ \\
\hline 12 & Ndima River & Umuna & Imo River & $"$ & $"$ \\
\hline 13 & Alum River & Okigwe & Imo River & $"$ & $"$ \\
\hline 14 & Uyin River & Okigwe & Imo River & $"$ & $"$ \\
\hline 15 & Amayi River & Okigwe & Imo River & $"$ & $"$ \\
\hline 16 & lyeochara River & Okigwe & Imo River & $"$ & $"$ \\
\hline 17 & Ohia River & Okigwe & Law-law River & $"$ & $"$ \\
\hline 18 & Law-Law River & Okigwe & Imo River & $"$ & $"$ \\
\hline 19 & Ugbi River & Nneafor & Okuini River & $"$ & $"$ \\
\hline 20 & Ezeze River & Okigwe & Onyimbo River & $"$ & $"$ \\
\hline
\end{tabular}




\begin{tabular}{|c|c|c|c|c|c|}
\hline 21 & Onyimbo River & Umunumo & Imo River & $"$ & $"$ \\
\hline 22 & Biyi River & Ikpa Okoto Ovim & Nfro River & Tributary & $\begin{array}{l}\text { Mbaise / Mbano water shed / } \\
\text { River Basin }\end{array}$ \\
\hline 23 & Upo River & Afugiri & Eme River & $"$ & $"$ \\
\hline 24 & Eme River & Afugiri & Imo River & $"$ & $"$ \\
\hline 25 & Obiyi River & Ikpa Okoto Ovim & Eme River & $"$ & $"$ \\
\hline 26 & Nfro River & Ihitte-Uboma & Imo River & $"$ & $"$ \\
\hline 27 & Onuiyiyin River & Obowo/ Ihitte- Uboma & Imo River & $"$ & $"$ \\
\hline 28 & Asa River & Nsu & Imo River & $"$ & $"$ \\
\hline 29 & Abadaba River / Lake & Ihitte-Uboma & Imo River & $"$ & $"$ \\
\hline 30 & Mba River & Amaraku & Oramiriukwa & Major lake & Orlu water shed / River Basin \\
\hline 31 & Okitankwo River & Umudi & Oramiriukwa & Tributary & " \\
\hline 32 & Oramiriukwa River & Isu & Otamiri & $"$ & $"$ \\
\hline 33 & Njaba River & Nkwere & Oguta Lake & Principal Tributary & $"$ \\
\hline 34 & Imo River & Ideato & Atlantic Ocean & Major River & $"$ \\
\hline 35 & Okuini River & Arondizuogu & Imo River & Tributary & $"$ \\
\hline 36 & Orashi River & Dikenafai/Umudi & Oguta Lake & " & $"$ \\
\hline 37 & Anamini River & Osina & Ahanum River & $"$ & $"$ \\
\hline 38 & Ahanum River & Akokwa & Imo River & $"$ & $"$ \\
\hline 39 & lyodo River & Akokwa & Ahanum River & $"$ & $"$ \\
\hline 40 & Ore River & Ntueke & Ahanum River & $"$ & $"$ \\
\hline 41 & Awkwa River & Ntueke & Ahanum River & Tributary & Oguta watershed / River Basin \\
\hline 42 & Eyin River & Oguta & Orashi River & " & " \\
\hline 43 & Awbana River & Mgbidi & Oguta Lake & $"$ & $"$ \\
\hline 44 & Utu River & Njaba & Oguta Lake & $"$ & $"$ \\
\hline 45 & Onas Creek & Egbema & Swamp & $"$ & $"$ \\
\hline 46 & Oguta Lake & Oguta & & Major lake & $"$ \\
\hline 47 & Osian Lake & Oguta & & Tributary & $"$ \\
\hline 48 & Asa River & Oguta & Oguta Lake & $"$ & 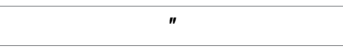 \\
\hline 49 & Nworie River & Egbeada & Otamiri & Tributary & Owerri water shed / River Basin \\
\hline 50 & Ogochie River & Umuneke-Ngor & Imo river & " & " \\
\hline 51 & Otamiri River & Egbu & Imo River & $"$ & $"$ \\
\hline
\end{tabular}

Table 1: Classification of Rivers / Lakes of Imo state.

\section{Practical Applications of the Hydrology of Rivers of Imo State for Water Resources Management}

According to Sharma and Sharma [7] and Reddy [8], the hydrology of a state or region plays an important role in the planning of water resources for sustainable development compatible with quantity, quality and environmental requirements. The principal applications of hydrology of the river of a region or state are thus:

\section{Water supply}

The knowledge of hydrology of the rivers of a state or region is used to determine the surface storage needed to meet the demand and the probability of availability of the required volume of water vis-à-vis occurrence of shortage and its frequency. It also helps to determine the location of wells, their safe yield and quality of water. All the rivers in Imo state can be used to provide adequate water supply for the cities and villages in Imo state.

\section{Agriculture}

Agriculture is one of the major users of surface water; therefore, the knowledge of surface hydrology of the environment helps in the determination of the volume of water available in the area and its frequency, extent of storage required, design of canal system(s) and other sources of water, storage facilities such as tanks, wells, tube wells, irrigation scheduling, soil moisture requirements of crops and optimum withdrawal of ground water etc. Mechanized agriculture can provide more productive practices in every farmland in Imo state with proper irrigations schemes from the rivers and lakes. Dams could be constructed in Njaba River and Mba River to provide water for irrigation for the farmers at Nkwere and Amaraku areas, respectively.

\section{Navigation}

Study of the rivers of Imo state will help to determine the availability of water, its volume and depth for water transportation and planning of navigation facilities. Imo River can be properly dredged for navigational purposes. Movement of goods and services along the Imo River will enhance commerce in the State. Small and large harbors can be constructed along the Imo River at Owerrinta to enhance commerce and recreation.

\section{Flood control}

Peak discharge, probability of its occurrence, pattern of flooding, flood protection measures, flood plain management, flood forecasting, etc, are determined by the hydrology of a region or state. Flood control problems are complicated because most of flood control projects modify the natural regime of the stream, and thus in the process of protecting one area, it may increase the flood damage in another. The technique of flood routing is essential to the effective and economic planning of flood control projects. When adequate hydro meteorological information is available, flood plain zoning may also be considered as one of the 
flood control measures. Dredging of Otamiri and Nwaorie Rivers and construction of flood control structures such as flood walls and levees will prevent flooding within Owerri urban area.

\section{Water pollution and its control}

Indiscriminate disposal of sewage from cities and industries into the nearby rivers and streams has resulted in hazards to the public and the destruction of the fish and the other wildlife. However, complete prevention of river pollution is not economically feasible. It is essential to identify streams and rivers that can handle certain amounts of waste water disposal (in terms of quality and quantity). This study will help to identify rivers for such purposes and control indiscriminate pollution of rivers, streams and lakes in the state. As the stream acts as a natural water purification system, it is generally considered permissible to allow disposal of certain effluents into streams. Government agencies should monitor and ensure that refuse and effluents are not disposed indiscriminately into the rivers, especially within Otamiri River, as it is the source of portable water supply in Owerri Municipal.

\section{Land use change and soil conservation}

Hydrology of the rivers and watersheds helps to determine soil erosion and conservation measures needed to mitigate them. The knowledge of the existing watershed management practices will help in finding out the effective erosion control measures suitable for the given soil condition. Soil conservation measures like contour bunds, terraces, gully plugging, vegetative cover (strip cropping), afforestation and stream bank protection are very necessary to control soil erosion and retard the velocity of runoff into Law-Law River, Orashi River and other rivers and lakes in Imo state (Table 1).

\section{Droughts}

Probabilities of occurrence of droughts are determined from proper knowledge and application of hydrological and meteorological information about a region or area. The use of hydrology helps in drought proofing of an area with the provision of irrigation and storage facilities. Small and large dams and storage reservoirs could be constructed in most of the rivers in Imo state to provide water all year round for rural and urban areas. This is necessary because some villages like Umudi and Orodo suffer from water scarcity during dry season as the Okitankwo River, their water supply, is not perennial. Therefore, there is need to store more water during the dry season.

\section{Flora and fauna}

A hydrological study of Imo State has helped to determine the effect of afforestation, deforestation, vegetation, construction activities like road construction and others on the quantity and quality of water generated from such catchment areas and how they impact wildlife, aquatic life and other ecosystems of the environment.

\section{Hydraulic structures}

Hydrological designs of dams, barrages, bridges, etc, require determination of peak discharge generated from a catchment and probability of its occurrence to the importance of the structure. Large and small dams should to be constructed in some of the villages and cities in Imo state such as Egbu, Okigwe, Ihitte-Uboma, Ogbaku, Ettiti, Afugiri and Ideato, as there are needs for storage and distribution reservoirs to store and supply water for domestic use, irrigation and others.

\section{Rural development}

Hydrological studies like this help to formulate rural development facilities such as water supply, drainage, sanitary systems, landscape, etc. All the rural communities in Imo State will develop speedily if all the rivers are harnessed and modeled for use in water resources projects in the communities.

\section{Urban development}

The availability of water is often the most important factor in locating major industries and it has considerable effect on urban development and the growth of municipalities. Hydrology determines peak floods and their frequency in addition to delineation of flood channel, floodplain, safe areas for urban development, drainage, recreation and waste water disposal systems.

\section{Energy}

Hydrological studies of an area are essential for planning of any water-power (energy) development. It helps to determine the feasibility of the run-of-river plant operations, and if ponds are required. Besides, a reliable prediction is needed of the absolute minimal daily flow that may be expected in the river or stream and of the percentage of time that various other flows are expected to exist. This study will help to determine the water availability for cooling purposes in thermal and nuclear power plants. Imo River, if properly harnessed, could be used for hydropower generation for the state.

\section{Environmental aspect}

Hydrological study of a region or state determines the environmental degradation caused by unscientific mining, over grazing, deforestation, sedimentation, fertilizers, pesticides and their impact on land area including surface and ground water.

\section{Other uses}

Water sports, recreation, and pisciculture require application and knowledge of the hydrology of the region in the determination of quantity and quality of water availability with regard to time and space for planning these uses. Imo River, Ahanum River, Biyi River, Anamini River, Nfro River, Awbana River, and Oguta Lake, if properly dredged and harnessed, could be used for water sports, recreation and fish farming.

The practical applications of the hydrology of a state or region can be made possible in Imo State by having a thorough knowledge of the rivers and lakes in Imo State as provided by this study.

\section{Water resources management}

According to Global Water Partnership [21], "Water is an essential natural resource that shapes regional landscapes and is vital for ecosystem functioning and human well-being". Water is essential for socio-economic development and for maintaining healthy ecosystems. A properly managed water resource is a critical component of poverty reduction, growth and equity. Water resources management involves planning, developing, distributing and managing the optimum use of water resources. It aims at optimizing the available natural water flows (both groundwater and surface water) to satisfy competing water needs. The functions of water resources management are very complex tasks and may involve many different activities conducted by many different players. Global Water Partnership [21] highlighted the following components which constitute water resources management: water allocation, river basin planning, stakeholder participation, pollution control, monitoring, economic and financial management, and information management.

Water allocation: Effective allocation of water to major water users 
and uses, maintaining minimum levels for social and environmental use while addressing equity and development needs of society in the State is very necessary. At the moment, potable water supply could only be provided to two towns in Imo state: Owerri and Okigwe. Other towns and communities within the State suffer scarcity of water, if not for boreholes water provided by few individuals within the communities. The knowledge of the river basins of Imo state for sustainable water resources management will assist in effective water resources allocation in the state, to prevent conflict and to manage the existing natural resource adequately.

River basin planning: The first step in developing a strategic plan is to get a clear idea of the water and land resource management issues and the ongoing activities in a basin. This will be followed by preparing and regularly updating the basin plan and incorporating stakeholder views on the development and management priorities for the basin. Therefore, legal principles requiring equal share of water resources and the sustainable management of the river basins and treaties according to water quantity and quality, their administrative structures, as well as, geopolitical institutions like river basin organizations have to be created in Imo state, as basin wide networks and river basin organizations attenuate conflict.

Stakeholder participation: Implementing stakeholder participation as a basis for decision making that takes into account the best interests of society and the environment in the development and use of water resources in the basin. All stakeholders and water users in Imo state could be enlightened through lectures and seminars by the State water management authorities for more efficient and sustainable water resources management. Procedures for involving stakeholders need to be designed thoughtfully and implemented carefully. Taking part in village meetings, 'town hall' meetings, surveys of basin stakeholders' opinions and basin advisory groups, are just some of the ways stakeholders can be encouraged to get involved. Workshops and field trips can help both stakeholders and basin organizations appreciate the array, size and extent of land and water resources issues in basin management, as well as how local actions impact other parts of the basin (Global Water Partnership and International Network of Basin Organizations) [10].

Pollution control: Managing pollution using "Polluter pays principles" and appropriate incentives to reduce the most important pollution problems and minimize environmental and social impact are required in Imo state. Refuse disposal and pollution of Nworie River can be controlled since the river is the main source of potable water supply in the State capital (Owerri municipal).

Monitoring: Local water laws and policies are the rules of the game that determine how all stakeholders play their respective roles in the development and management of water resources. Thus, the State should implement effective monitoring systems that provide essential management information, and identifying and responding to infringements of laws, regulations and permits. Imo state government should monitor public (administrative) allocation of water, which is used for intersectoral allocation of water, since the state, usually, is the only institution that has jurisdiction over all sectors of the economy.

Economic and financial management: It is important to apply economic and financial tools for investment, cost recovery and behavior change to support the goals of equitable access and sustainable benefits to society from water use. The State should identify and implement measures for governance and increasing the efficiency of water use, by always carrying out cost-benefit analysis in order to compare the economic efficiency implication of alternative actions. Besides, economic efficiency is one of the primary objectives in the development and allocation of water resources because of its importance as a social objective, since efficiency values have viable meaning in resolving conflicts and assessing the opportunity costs of pursuing alternative uses of water.

Information management: Basin organizations need to create a basin information system that generate data and indicators on water resources and water use that will allow effective assessment of water management. Providing essential data necessary to make informed and transparent decision as well as development and sustainable management of water resources in the basin is very crucial to the development of an appropriate menu of adaptation and mitigation options for addressing hydrologic variability and climate change in water management. Information such as river stage(s) and river discharge(s) should be recorded by Imo state government water management authorities and river basin authorities, as they are necessary for water resources management. This will enhance adequate water allocation and sustainability of this depleting natural resource within Imo state.

The knowledge of all these rivers and lakes in Imo state is important for various water resources planning, management and investigation processes in water projects. Besides, special studies are required to know the quantity of water that has to be dealt with over long periods of time and when it is desirous to use water at uniform or nearly uniform rates greater than the minimum discharges in the streams and rivers. It is also necessary to provide storages when water is impounded during periods of high flows for use during periods of low flows. Mass curve (a graph that shows the cumulative depth of rainfall against time and the slope at any point giving the rate of rainfall) serves as a very useful tool to determine the required storage capacity for any uniform rate of demand.

\section{Summary}

As stated earlier, Imo state is well drained by rivers and lakes as shown in (Figure 3 and Table 1). Imo state derives a lot of benefits from all these rivers and lakes. This study of the hydrology of Imo state will serve as a baseline on rivers, lakes, etc. It will also serve as a reference benchmark on the water resources of the state. The water supply from these rivers and lakes has many competing uses; as a result, they are predisposed to pollution. Thus, there is need for water quality management in order to achieve sustainable water resources management with accurate information on the conditions and trends of the rivers and lakes. All data must be collected to conform to a set standard, which must be a national standard so that all data must be comparable, compatible and of sufficient accuracy. A law guiding the use of water resources in the state is necessary for the protection of our water resources. An accurate water resources inventory is a necessity in the state. Feasibility studies on the electric power potentials of Imo state should be conducted as a matter of necessity.

\section{Conclusion and Recommendations}

This study that aimed at identifying rivers, streams, lakes and their basins in Imo state, will help in further studies for the determination of the quantity of water available for irrigation, hydro-power, municipal and industrial water supply, rural water supply, navigation and other various purposes. These studies (now and future) will also be useful in the design and operation of hydraulic structures, flood control, soil erosion control, pollution abatement, fish and wild life protection. The knowledge of the rivers and lakes in Imo state will help analyze the problems involved in water resources allocation and to provide guidance for the planning and management of water resources, as measurements 
are the only reliable indicators of the status and trend of the available water resources in the state or region. It is necessary to state that before this study, there seems not to be a documented record of the rivers, streams, lakes and basins of Imo state. This study is therefore essential for making decisions that concern water resources allocation.

It is therefore recommended that:

a. Research Institutes, Federal and State Ministries of Agriculture and Natural Resources and various River Basin Development Authorities in Nigeria could make use of this study to provide stream flow data of these rivers in Imo state for long periods of time for stream flow modeling studies, and other similar studies, that will solve water resources problems in various regions.

b. Design and construction of hydraulic structures, water supply systems, irrigation, drainage, flood control, erosion and sedimentation control, and pollution abatement works that depend on specific river studies and on this type of study that identifies rivers of a state, should be handled by engineers who will adhere to the stream flow models and other water resource management models. Results obtained should be used in these rivers in particular and other localities where water resources structures and control works are to be located.

\section{References}

1. Garg SK (2012) Hydrology and Water Resources Engineering, $16^{\text {th }}$ revised edition. Delhi: Khanna Publishers.

2. Gupta BL, Gupta A (2008) Water Resources Systems and Management $\left(2^{\text {nd }}\right.$ edition): Standard Publishers Distributors, Delhi, India.

3. Arora KR (2011) Irrigation Water Power and Water Resources Engineering (4th edition): Standard Publisher Distributors, Delhi, India.

4. Wisler CD, Brater EF (1959) Hydrology. New York: John Wiley and Sons.

5. Viessman W, Lewis GL (2003) Introduction to Hydrology (5th edition) Ghost, Prentice-Hall of India Private Limited, New-Delhi, India.

6. Chow VT, Maidment DR, Mays LW (1988) Applied Hydrology. New York: McGraw-Hill Book Company.
7. Sharma RK, Sharma TK (2000) A Text Book of Hydrology and Water Resources Engineering. Dhanpat Rai Publications (P) Limited, New Delhi, India.

8. Reddy PJR (2008) A Textbook of Hydrology. University Science Press, New Delhi, India.

9. Global Water Partnership and International Network of Basin Organizations (2009)

10. National bureau of Statistics (2012) Imo State Information.

11. Atlas of Imo State (1984) Ministry of Lands, Survey and Urban Planning, Owerri Imo State.

12. Chimezie NM (2006) Planning Hydrometric network for Imo River Basin. (M Eng Thesis, Unpublished).

13. Nwachukwu BA (1989) Planning Hydrometric network for Imo State Nigeria Water Resources Journal, Nigeria. Association of Hydrogeologist.

14. Onweremadu EU (2007) Soil Mercury Distribution in a Forest-Savanna Mosaic in Relation to Soil Fertility. Research Journal of Environmental Toxicology 1: 158-166.

15. Uma KO, Kehinde MO(1992) Quantitative assessment of the groundwater potential of small basins in parts of southeastern Nigeria. Hydrological Sciences 31: 4-8.

16. Acholonu ADW (2008) Water quality studies of Nworie River in Owerri, Nigeria Journal of the Mississippi Academy of Sciences.

17. Ananaba SE, Onu NN, Iwuagwu CJ (1993). Geophysical study of the gravel deposit in Ihiagwa, Owerri, Nigeria. Journal of Mining Geology, 29: 95-100.

18. Ogidi MI, Nwadiaro CS (1988) Geophysical Limnology of Lake Oguta, Southeastern Nigeria. Hydrobiological Bulletin 22: 113-126.

19. Ahiarakwem CA, Onyekuru SO (2011) A Comparative Assessment of the Physico-Chemical and Microbial Trends in Njaba River, Niger Delta Basin Southeastern Nigeria. Journal of Water Resource and Protection 3: 686-693.

20. Ahiarakwem CA (2006) Water quality assessment and some geochemical models of Oguta Lake, south eastern Nigeria. Unpubl PhD Thesis, Fed Univ of Tech, Owerri.

21. Global Water Partnership (2012) Water Resources Management. 